\title{
Is the NHS really safe from international trade agreements?
}

\author{
Lessons have come from Slovakia
}

\section{Lucy Reynolds research fellow, London School of Hygiene and Tropical Medicine, UK, Martin McKee professor of European public health, London School of Hygiene and Tropical Medicine}

International trade agreements generally attract little public scrutiny in the United Kingdom, but while some are uncontroversial, others are not. ${ }^{1}$ One, the Transatlantic Trade and Investment Partnership (TTIP), ${ }^{2}$ currently being negotiated between the European Union and United States, even features in the 2015 UK general election manifestos, with all three main parties supporting it, albeit with certain reservations, and upcoming parties such as the Green Party and National Health Action Party opposing it. ${ }^{3}$ There are concerns that TTIP, which will cover over $40 \%$ of the world's economy, would enable global corporations to over-ride a future UK government seeking to reverse aspects of NHS privatisation, ${ }^{4}$ potentially leading to the replacement of the NHS with a US style market based system.

The UK government could opt to remove many aspects of healthcare from the scope of TTIP, just as the French government has excluded its cultural sector. Yet the coalition government has declined to do so, arguing that this is unnecessary. Prime Minister David Cameron described fears that the TTIP might damage the NHS as "bogus nonsense" and an "empty threat." Vince Cable, the Liberal Democrat business secretary, said confidently that there would be no requirement for a future government to open up more NHS services to competition or private provision. ${ }^{7}$ Both refer to the EU commissioner for trade, who has sought to "correct some of the misconceptions circulating," ${ }^{8}$ asserting that nothing in TTIP would require a national government to privatise health services or prevent it from bringing previously privatised services back into the public sector. Similar reassurances have been given by other European Commission officials and cited extensively by UK ministers.

But are they right? Are those expressing concern, including a wide range of non-governmental organisations such as the UK's Faculty of Public Health, ${ }^{9}$ misinformed or scaremongering? A tribunal report that has just been released under freedom of information procedures indicates that there really is a problem.

\section{Bypassing the courts}

An appreciation of how trade agreements work helps in understanding that problem. Because courts often fail to support companies, ${ }^{10}$ as with the failure by Japan Tobacco International to overturn Australia's ban on branded packaging, ${ }^{11}$ large corporations and certain governments initiated an alternative, the Investor-State Dispute Settlement (ISDS) system. ${ }^{12}$ This allows corporations whose profits are threatened, such as by controls that could reduce the number of cigarettes they sell, to overturn public health decisions by elected governments. ISDS bypasses the courts: rulings are given instead by commercial arbitrators with no requirement to accommodate public policy objectives. ISDS is a core element of the TTIP.

Why this is important is apparent from an ISDS Tribunal case arising from the 2008 decision by the Slovakian government to require health insurers to be not for profit, a principle previously ruled as lawful under European law by the European Court of Justice..$^{13}$ An Austrian bank that owned shares in one of the previous for-profit companies - thus once removed from any agreement between the government and the insurers-claimed compensation for loss of the money that it might have made if profit making from national health insurance had continued. It invoked an Austria-Slovakia investment agreement negotiated in 1990 by the Czechoslovak government and inherited by Slovakia. ${ }^{14}$ This treaty allows commercial entities to claim compensation from public funds through ISDS style "investor protection" rules against "expropriation" (otherwise known as renationalisation).

Given the European Commission's stated confidence that the TTIP could not be used to circumvent national governments and courts, it was unsurprising that it argued before the 2010 Slovak trade tribunal set up to hear the case that the tribunal had no right to do so and that such matters should be settled by the courts, with the European Court of Justice as final authority. The trade tribunal rejected this view, ruling that that court had no monopoly in determining interpretation of European law. Although the Slovakian government ultimately prevailed, 
because of technical flaws in the case against it, this tribunal report clarifies several important points.

Firstly, opinions of European Commission officials or government ministers, Slovak or British, about what an international trade agreement permits or prevents cannot be considered definitive.

Secondly, even indirect investors in public services may be able to penalise governments financially if they seek to roll back the market in healthcare. They will do this not in the courts, which apply the law in the public gaze and can accommodate public policy concerns, but in secret arbitration tribunals.

Thirdly, had Slovakian freedom of information law not permitted the release of the details of this case we would never have known about them.

We still don't know what is being discussed in the negotiations on the TTIP. But now we may well draw less comfort from official reassurances.

\section{Competing interests: None declared.}

Provenance and peer review: Commissioned; not externally peer reviewed.

thebmj.com Editorial: The Transatlantic Trade and Investment Partnership and UK healthcare (BMJ2014;349:g6552, doi:10.1136/bmj. g6552); Feature: Trade secrets-will an EU-US treaty enable US big business to gain a foothold? (BMJ 2013;346:f3574, doi:10.1136/bmj. f3574)

For more from The BMJ on the UK general election go to bmj.co/election.
1 Freeman S. NAFTA's chapter 11 makes Canada most-sued country under free trade tribunals. Huffington Post 14 Jan 2015. www.huffingtonpost.ca/2015/01/14/canada-suedinvestor-state-dispute-ccpa_n_6471460.html.

2 Holden D. TTIP: the biggest threat to democracy you've never heard of. New Statesman 5 Sep 2014. www.newstatesman.com/politics/2014/09/tip-biggest-threat-democracyyouve-never-heard.

3 lacobucci G. What the political parties are pledging on the NHS. BMJ 2015;350:h2031.

4 Davis J, Lister J, Wrigley D. NHS for sale: myths, lies and deception. Merlin Press, 2015. Kaucher L. The real force behind the NHS Act: the EU-US trade agreement. Open Democracy 19 February 2013. https://www.opendemocracy.net/ournhs/linda-kaucher/ real-force-behind-nhs-act-euus-trade-agreement.

6 Wintour P. David Cameron vows he will take the fight to unions over US-EU trade deal. Guardian 16 Nov 2014. www.theguardian.com/politics/2014/nov/16/david-cameron-fightunions-us-eu-trade-deal.

7 Cable V. Letter to all members of parliament: the Transatlantic Trade and Investment Partnership. UK Department of Business, Innovation and Skills. 2014. https://www.gov. uk/government/publications/transatlantic-trade-and-investment-partnership-ttip-letter-fromvince-cable-to-all-mps.

8 Malmström C. NHS and TTIP: letter from EU trade commissioner Cecilia Malmström, 2015. Department for Business, Innovation and Skills, 2015. https://www.gov.uk government/publications/nhs-and-ttip-letter-from-eu-trade-commissioner-cecilia-malmstrom.

9 Weiss M. Trading Health? UK Faculty of Public Health Policy Report on the Transatlantic Trade and Investment Partnership. Faculty of Public Health, 2015. www.fph.org.uk/uploads/ FPH\%20Policy\%20report\%20on\%20the\%20Transatlantic\%20Trade\%20and\% 20Investment\%20Report\%20-\%20FINAL.pdf.

10 Steele S, Gilmore AB, McKee M, Stuckler D. Systematic review of domestic tobacco litigation strategies and outcomes in high-income countries, 1994-2014.J Publ Health [in press].

11 Australian High Court. JT International SA v Commonwealth of Australia. HCA 432012.

12 Jarman H. Public health and the Transatlantic Trade and Investment Partnership. Eur J Public Health 2014;24:181.

13 McKee M, Mossialos E, Baeten R. The impact of EU law on health care systems. Peter Lang, 2002.

14 Hepburn J, Peterson LE. In hitherto unpublished ruling, Greenwood/Stern Tribunal reject plea that intra-EU BIT was implicitly terminated under VCLT due to EU accession. IA Reporter 2 Apr 2015. www.iareporter.com/articles/20150402_3.

Cite this as: BMJ 2015:350:h2179

(c) BMJ Publishing Group Ltd 2015 